University of Nebraska - Lincoln

DigitalCommons@University of Nebraska - Lincoln

USDA Wildlife Services - Staff Publications

U.S. Department of Agriculture: Animal and Plant Health Inspection Service

3-1-2021

\title{
Avian visual ecologists should consider UV absorbance and all sensory modalities: A response to Wisenden et al. (2020)
}

\author{
Sean T. O'Daniels \\ University of Missouri, odaniels.sean@gmail.com \\ Scott J. Werner \\ USDA APHIS National Wildlife Research Center \\ Ken Yasukawa \\ Beloit College
}

Follow this and additional works at: https://digitalcommons.unl.edu/icwdm_usdanwrc

Part of the Natural Resources and Conservation Commons, Natural Resources Management and Policy Commons, Other Environmental Sciences Commons, Other Veterinary Medicine Commons, Population Biology Commons, Terrestrial and Aquatic Ecology Commons, Veterinary Infectious Diseases Commons, Veterinary Microbiology and Immunobiology Commons, Veterinary Preventive Medicine, Epidemiology, and Public Health Commons, and the Zoology Commons

O'Daniels, Sean T.; Werner, Scott J.; and Yasukawa, Ken, "Avian visual ecologists should consider UV absorbance and all sensory modalities: A response to Wisenden et al. (2020)" (2021). USDA Wildlife Services - Staff Publications. 2498.

https://digitalcommons.unl.edu/icwdm_usdanwrc/2498

This Article is brought to you for free and open access by the U.S. Department of Agriculture: Animal and Plant Health Inspection Service at DigitalCommons@University of Nebraska - Lincoln. It has been accepted for inclusion in USDA Wildlife Services - Staff Publications by an authorized administrator of DigitalCommons@University of Nebraska - Lincoln. 


\title{
Avian visual ecologists should consider UV absorbance and all sensory modalities: A response to Wisenden et al. (2020)
}

\author{
Sean T. O’Daniels, ${ }^{1} *$ Scott J. Werner, ${ }^{2}$ and Ken Yasukawa ${ }^{3}$
}

\begin{abstract}
In a recent publication, Wisenden et al. (2020) examined responses of territorial male Red-winged Blackbirds (Agelaius phoeniceus) to models constructed with ultraviolet (UV)-reflective red epaulets for the purpose of determining if the addition of UV reflectance to epaulets ("UV+") changed the effectiveness of signals to receivers relative to "control" epaulets under field conditions. The authors hypothesized that "UV+epaulet coloration represents a visual signal with increased efficacy in territorial interactions." They presented behavioral data but no visual modeling data. Our aims in this commentary are to suggest alternative terms to those used by the authors, to express concern about the use of sunscreen to manipulate the UV condition of surfaces, and to make a plea for additional data collection in future studies of avian visual ecology. The terms $\mathrm{UV}+$ and UV- should be reserved for studies that create environments free from UV radiation for comparison with environments that include UV radiation. We believe that commercial sunscreens are not an appropriate choice for altering the UV conditions of surfaces presented during behavioral trials because they potentially introduce confounding influences from other sensory inputs or irritation of peripheral nerves. Wisenden et al. altered the UV absorbance of their sunscreen-treated models but did not present absorbance spectra and may not have collected those data. We acknowledge that the lack of absorbance spectra is not unusual. We implore any such future studies to collect absorbance spectra of treated and control surfaces so that those data may be used to improve visual models for UVsensitive animals. Received 27 October 2020. Accepted 4 March 2021.
\end{abstract}

Key words: signal evolution, territory defense, ultraviolet color, visual ecology.

\section{Los ecólogos visuales de aves deben considerer la absorbencia UV y todas las modalidades sensoriales: respuesta a Wisenden et al. (2020)}

RESUMEN (Spanish) - En una publicación reciente, Wisenden et al. (2020) examinaron las respuestas de machos territoriales del tordo Agelaius phoeniceus a modelos construidos con charreteras rojas reflejantes ultravioletas (UV) con el propósito de determinar si la

\footnotetext{
${ }^{1}$ Independence, MO, USA

${ }^{2}$ US Department of Agriculture, Animal \& Plant Health Inspection Service, Wildlife Services, National Wildlife Research Center, Ft. Collins, CO, USA

${ }^{3}$ Beloit College, Department of Biology, Beloit, WI, USA

* Corresponding author: odaniels.sean@gmail.com
}

adición de reflectancia a las charreteras ("UV+") cambiaba la efectividad de las señales dirigidas a receptores en relación con charreteras "control" bajo condiciones de campo. Los autores tenían la hipótesis de que "la coloración UV+ de las charreteras representa una señal visual con eficacia aumentada en interacciones territoriales". Los autores presentaron datos conductuales pero no datos de modelado visual. Nuestra meta en este comentario es sugerir términos alternativos a aquellos empleados por los autores, expresar preocupación por el uso de bloqueador solar para manipular la condición UV de superficies y hacer un llamado para la colecta de datos adicionales en futuros estudios de ecología visual aviar. Los términos UV+y UV- deben estar reservados para comparaciones con ambientes que incluyan radiación UV. Pensamos que el uso de bloqueadores solares comerciales no es una elección adecuada para la alteración de las condiciones UV de superficies durante pruebas de comportamiento porque podrían introducir influencias confusas provenientes de otras señales sensoriales o irritar nervios periféricos. Wisenden et al. alteraron la absorbencia UV de sus modelos tratados con bloqueador solar pero no presentaron espectros de absorbencia y podrían no haber colectado esos datos. Reconocemos que la carencia de espectros de absorbencia no es inusual. Pedimos que cualquier estudio futuro colecte espectros de absorbencia en superficies tratadas y controles para que esos datos puedan ser usados para mejorar los modelos visuales de animales sensibles a UV.

Palabras clave: color ultravioleta, defensa de territorio, ecología visual, evolución de señales.

In a recent publication, Wisenden et al. (2020) examined responses of territorial male Red-winged Blackbirds (Agelaius phoeniceus) to conspecific male models constructed with ultraviolet (UV)reflective red epaulets for the purpose of determining if the addition of UV reflectance to epaulets ("UV+") changed the effectiveness of signals to receivers relative to "control" epaulets under field conditions. Human sunscreen (SPF-50) was applied to UV-reflective red felt to create "normal" epaulet coloration, or "control" models ("UV-").

Wisenden et al. hypothesized that "UV+ epaulet coloration represents a visual signal with increased efficacy in territorial interactions." We regard this hypothesis as interesting and worthy of testing, and we appreciate Wisenden et al.'s efforts to conduct their test in the field. Given our current understanding of the UV visual system of Red-winged Blackbirds and the methodologies currently available to investigate avian vision, however, we feel 
compelled to raise a few points of concern with both the terminology and methods of Wisenden et al.

Our aims in this commentary are to suggest alternative terms to those used by the authors, to express concern about the use of sunscreen to manipulate the UV condition of surfaces, and to make a plea for additional data collection for available perceptual modeling in future studies of avian visual ecology. More broadly, we hope that our commentary will be useful in unifying the field of visual ecology moving forward.

Wisenden et al. (2020) presented model male Red-winged Blackbirds along with recorded species-specific songs to territorial males in situ. The epaulets of these models were constructed with UVreflective red felt material, and half were treated with SPF-50 sunscreen ("controls") in an attempt to produce epaulets with "normal" reflectance. First, we note that the authors used the term "control" unconventionally. Typically, application of sunscreen to red felt would be the experimental manipulation and the unmanipulated felt would serve as the control. The authors also used the terms $\mathrm{UV}+$ and UV- to describe the 2 experimental conditions. We believe, however, that these terms are problematic as used here because they do not accurately describe the ultraviolet conditions of the models presented to focal territorial males. We suggest the proper terminology for Wisenden et al.'s study should be UV-reflective (-ing) for unmanipulated epaulet models and UV-absorptive (-bing) for sunscreen-treated models. The terms UV+and UVshould be reserved for studies that create environments free from UV radiation for comparison with environments that include UV radiation (i.e., Church et al. 1998).

Why does this distinction matter? For UVsensitive animals, treating surfaces with UVabsorbing compounds creates a recognizable difference from untreated control surfaces (Werner et al. 2012, O'Daniels et al. 2017) and does not remove UV (as the term UV- suggests); it merely makes the treated surface more UV-absorbing. Additionally, surfaces (including bird feathers) can be simultaneously UV-reflecting and UV-absorbing (Pearn et al. 2003) as these properties are controlled by different mechanisms. It is therefore necessary to compare absorbance spectra, which were not reported and may not have been collected, in addition to reflectance spectra. We will expand on this point later in our commentary. The use of taxidermized male Red-winged Blackbirds, or natural epaulet feathers (even whole wings) mounted on model bodies, would have been a better choice for controls (i.e., models with unmanipulated, "normal" epaulets) particularly if the authors were unable to find a red felt material that was not UV-reflective, and would allow comparisons with both UV-reflective and UVabsorptive models. Use of such models for control purposes could have strengthened the authors' conclusions regarding behavioral responses to elevated UV reflectance, or perhaps led them to different conclusions.

In a study of plumage reflectance, absorbance, and fluorescence, Pearn et al. (2003) cautioned that sunscreen applications may have unintentional effects on mate choice. We agree with that cautionary statement and also believe that commercial sunscreens are not an appropriate choice for altering the UV conditions of surfaces presented during behavioral trials because they potentially introduce confounding influences from olfaction, taste, or other sensory input such as irritation of peripheral nerves (Clark et al. 2014). Avian olfaction outside of vultures (Accipitridae, Cathartidae) has been historically understudied, but recent work shows that olfaction is likely an important sense across avian taxa (Corfield et al. 2015, Rossi et al. 2017, Mäntylä et al. 2020). Similarly, recent work in avian taste perception shows it is also likely an important sense in a variety of taxa (Wang and Zhao 2015, Hämäläinen et al. 2020).

Trigeminal irritants (e.g., methyl anthranilate) have proven to be effective avian repellents in a variety of nuisance and damage control settings, including against Red-winged Blackbirds (Avery et al. 1995, Werner and Avery 2017). We are concerned that alcohols, botanical essential oils, and other organic molecules often present in chemical sunscreens have the capacity to act in a similar fashion, that is, to irritate the peripheral nervous system of birds. In previous experiments, SJW and STO have used magnesium carbonate $\left(\mathrm{MgCO}_{3}\right)$ to increase UV reflectance of surfaces and titanium dioxide $\left(\mathrm{TiO}_{2}\right)$ or UV Killer (Atsko, Orangeburg, South Carolina, USA) to increase UV absorbance. We suggest that solutions or suspensions of base compounds (e.g., $\mathrm{MgCO}_{3}, \mathrm{TiO}_{2}$ ) should be used wherever possible when altering the UV condition of surfaces, and products free 
from perfumes or volatile-producing compounds be used when base compounds will not work. Wisenden et al. (2020) show that territorial male Red-winged Blackbirds reacted more strongly to the untreated, UV-reflective models and conclude that the difference in UV condition between models is the explanation. We agree that this conclusion is entirely plausible, but the authors do not offer alternative explanations for these observed behaviors nor any acknowledgment of potentially confounding sensory inputs (e.g., avoidance of sunscreen-treated models due to trigeminal irritation). Failure to account for nonvisual sensory inputs is a potential flaw in behavioral studies of visual perception, and we therefore encourage future researchers, reviewers, and editors to ensure these possibilities are considered and acknowledged.

Wisenden et al. (2020) provide reflectance spectra of red epaulets to show how the sunscreen treatment affected their felt epaulets and how they compared with wild male epaulets. They state, "The long-wavelength (red) end of reflecting spectra of our models did not perfectly match the red of the natural epaulet but, we assume, was close enough to the natural epaulet to evoke responses, and in any case, the red of the felt models was present in both UV+ and UVtreatment and therefore did not contribute to differential responses to model types." We suggest that rather than assuming the spectra were "close enough," Wisenden et al. could have used available visual system data to model the differences and/or similarities between their 2 types of models. Although the red felt was present in both male models, because the UV-absorbing models were treated with sunscreen, analysis of their spectral data may have revealed subtle differences (i.e., perceptible to Red-winged Blackbirds) that would not be detected by visually comparing the sameness of average reflectance spectra.

At the time of their submission, species-specific visual system data for Red-winged Blackbirds that have since been published (Fernandez-Juricic et al. 2019) were not available; however, data for average passerine visual systems and other species were available and could have been used to approximate Red-winged Blackbird vision.

Perceptual modeling can be used to estimate the degree of visual conspicuousness of a visual signal from a species-specific visual perspective. Visual contrast models estimate in the chromatic and achromatic dimensions, and the degree of visual contrast of an object relative to its visual background. For the purpose of determining if the addition of UV reflectance to epaulets changed the effectiveness of signals relative to non-UVreflecting epaulets, contemporary perceptual models could have been developed based upon the key visual traits of an average passerine or surrogate species. The chromatic and achromatic contrasts of experimental treatments (e.g., UV-enhanced vs. unenhanced "control" models) could then be estimated, and Wisenden et al. could then have assessed the shape of the relationships between the degree of the visual conspicuousness and the behavioral responses of Red-winged Blackbirds to these experimental treatments. Rather, Wisenden et al. (2020) presented the comparative frequency of song spread and song flight to UV-reflective models relative to these responses to what the authors regarded as "normal" epaulet coloration. We acknowledge that lack of perceptual modeling data does not invalidate the behavioral data collected, but in this study we feel such data would have been a significant enhancement.

We remain curious about other agonistic behaviors associated with UV-reflective epaulets and the effectiveness of these experimental visual signals (e.g., success of intrasexual competition). Thus, we are left wanting for (1) the development of speciesspecific predictions and (2) a test of the hypothesis of Wisenden et al. (2020) regarding whether enhanced-UV epaulet coloration "represents a visual signal with increased efficacy in territorial interactions." With regard to our recommendations for additional data collection, we were surprised that Wisenden et al. (2020) did not discuss their non-repeated observations of (1) more song flight displays associated with UV-enhanced models in $2017(P=0.017 ; n=10)$ and not in $2019(P=$ $0.215 ; n=18)$ and (2) more song spread displays associated with UV-enhanced models in $2019(P=$ $0.016)$ and not in $2017(P=0.718)$.

Finally, as we noted before, Wisenden et al. (2020) altered the UV-absorbance of their sunscreen-treated models but did not present absorbance spectra and may not have collected those data. We acknowledge that the lack of absorbance spectra is not unusual; we are aware of no similar studies of visual perception that report absorbance spectra of surfaces, likely because models of avian vision (e.g., 
Vorobyev and Osorio 1998) have been constructed only considering input from reflectance spectra. Pearn et al. (2003) and Barreira et al. (2012) reported absorbance maxima for feather patches of interest (but no spectra), and Werner et al. (2012) reported absorbance spectra for a liquid seed treatment prior to, but not after, application. This field-wide lack of absorbance data acquisition and reporting exists despite Lythgoe and Partridge's (1989) observation more than 30 years ago that UV-sensitive animals are capable of detecting strongly UV-absorbing surfaces, a publication that according to Google Scholar (2020; https://scholar.google.com) has been cited 227 times. Their observation has been confirmed for both Red-winged Blackbirds (Werner et al. 2012) and Pileated Woodpeckers (Dryocopus pileatus; O'Daniels et al. 2017), although neither of those studies collected absorbance spectra of treated surfaces (a fact these authors regret). The methods presented in those 2 earlier studies and now by Wisenden et al. offer researchers the ability to easily manipulate the UV condition of surfaces, particularly regarding UV absorbance.

We implore any such future studies to collect absorbance spectra of treated and control surfaces so that those data may be used to improve visual models for UV-sensitive animals. We intend this commentary to be broadly useful in unifying and moving forward the field of visual ecology and not merely to highlight perceived shortcomings in the study presented by Wisenden et al. (2020), and sincerely hope that our comments will be taken as such.

\section{Acknowledgments}

We thank E. Ruelas Inzunza and 3 anonymous, voluntary reviewers for their editorial and thoughtful comments that improved a previous version of this manuscript.

\section{Literature cited}

Avery ML, Decker DG, Humphrey JS, Aronov E, Linscombe SD, Way MO. 1995. Methyl anthranilate as a rice seed treatment to deter birds. Journal of Wildlife Management. 59:50-56.

Berriera AS, Lagorio MG, Lijtmaer DA, Lougheed SC, Tubaro PL. 2012. Fluorescent and ultraviolet sexual dichromatism in the Blue-winged Parrotlet. Journal of Zoology. 288:135-142.

Church SC, Bennett ATD, Cuthill IC, Partridge JC. 1998. Ultraviolet cues affect the foraging behaviour of Blue
Tits. Proceedings of the Royal Society Series B. 265:1509-1514.

Clark L, Hagelin J, Werner S. 2014. The chemical senses in birds. In: Whittow GC, editor. Sturkie's Avian Physiology. 6th edition. San Diego (CA): Academic Press; p. 89-111.

Corfield JR, Price K, Iwaniuk AN, Gutiérrez-Ibáñez C, Birkhead T, Wylie DR. 2015. Diversity in olfactory bulb size in birds reflects allometry, ecology, and phylogeny. Frontiers in Neuroanatomy. 9:102.

Fernandez-Juricic E, Baumhardt PE, Tyrrell LP, Elmore A, DeLiberto ST, Werner SJ. 2019. Vision in an abundant North American bird: The Red-winged Blackbird. Auk. 136:1-27.

Hämäläinen L, Mappes J, Thorogood R, Valkonen JK, Karttunen K, et al. 2020. Predators' consumption of unpalatable prey does not vary as a function of bitter taste perception. Behavioral Ecology. 31:383-392.

Lythgoe JN, Partridge JC. 1989. Visual pigments and the acquisition of visual information. Journal of Experimental Biology. 146:1-20.

Mäntylä E, Kipper S, Hilker M. 2020. Insectivorous birds can see and smell systemically herbivore-induced pines. Ecology and Evolution. 10:9358-9370.

O'Daniels ST, Kesler DC, Mihail JD, Webb EB, Werner SJ. 2017. Functional visual sensitivity to ultraviolet wavelengths in the Pileated Woodpecker (Dryocopus pileatus), and its influence on foraging substrate selection. Physiology and Behavior. 174:144-154.

Pearn SM, Bennet ATD, Cuthill IC. 2003. The role of ultraviolet-A reflectance and ultraviolet-A induced fluorescence in the appearance of Budgerigar plumage: Insights from spectrofluorometry and reflectance spectrophotometry. Proceedings of the Royal Society B. 270:859-865.

Rossi M, Marfull R, Golüke S, Komdeur J, Korsten P, Caspers BA. 2017. Begging Blue Tit nestlings discriminate between the odour of familiar and unfamiliar conspecifics. Functional Ecology. 31:17611769.

Vorobyev M, Osorio D. 1998. Receptor noise as a determinant of colour thresholds. Proceedings of the Royal Society B. 265:351-358.

Wang K, Zhao H. 2015. Birds generally carry a small repertoire of bitter taste receptor genes. Genome Biology and Evolution. 7:2705-2715.

Werner SJ, Avery ML. 2017. Chemical repellents. In: Linz GM, Avery ML, Dolbeer RA, editors. Ecology and management of blackbirds. Boca Raton (FL): CRC Press; p. 135-158.

Werner SJ, Tupper SK, Carlson JC, Pettit SE, Ellis JW, Linz GM. 2012. The role of a generalized ultraviolet cue for blackbird food selection. Physiology and Behavior. 106:597-601.

Wisenden BD, Eaton MD, Arendall M, Bushlack BR, Clark IJ, et al. 2020. Male Red-winged Blackbirds (Agelaius phoeniceus) respond with greater intensity to epaulets with UV reflectance. Wilson Journal of Ornithology. 132:39-44. 